\section{P378 A WIDE VARIETY OF INTRAVAGINAL PRACTICES SHOULD BE CONSIDERED IN RESEARCH STUDIES IN RURAL SOUTH AFRICA}

${ }^{1} \mathrm{~L}$ Mlanjeni*, ${ }^{1} \mathrm{M}$ Mdingi, ${ }^{1} \mathrm{R}$ Gigi, ${ }^{1,2,3} \mathrm{R}$ Peters. ${ }^{1}$ Foundation For Professional Development, 10 Rochester Road, South Africa; 'University of Pretoria, Department of Medical Microbiology, Pretoria, South Africa; ${ }^{3}$ University of Cape Town, Division of Medical Microbiology, Cape Town, South Africa

\subsection{6/sextrans-2021-sti.414}

Background The vaginal microbiome and genital tract inflammation play an important role in HIV transmission and birth outcomes in South Africa. Intravaginal practices (IVPs) such as cleansing may influence the microbiome and levels of inflammation. IVPs are commonly practiced by women in South Africa, however, studies generally only include collection of data on cleansing and insertion of herbs.

Methods We conducted an exploratory study to obtain insight in the variety of IPVs practiced by women in the rural Eastern Cape province of South Africa. Group discussion was held with participants $(n=10)$ in an STI workshop and additional information was obtained through snowballing. Participants were two medical doctors, two project managers, two nurses, and four counsellors/social workers. IPVs that participants were aware of or had heard about were recorded.

Results Other than intravaginal cleansing and insertion of herbs, participants had knowledge of women inserting a variety of substances in their vagina such as snuff (tobacco powder), ice cubes, toilet refreshener, Chinese pills, uvutha wabafazi (a traditional vaseline-like ointment), Indian holy ash, soft drinks and Vicks VapoRub. Intravaginal use of live organisms (Kombucha aka Amoeba mabhebeza, frogs and snakes) was also known. In addition, genital steaming practice is common using water with salt, onion, avocado seeds, guava leaves. Finally, external and internal sanitary packs created of potato sack or newspaper are used. The purpose of all these practices was to enhance male sexual pleasure, genital health, for sexual fortune and energy, and for traditional healing purpose.

Conclusion Studies of genital tract microbiome and inflammation in women in rural South Africa should take a wide range of IPVs into account. Further research is required to document the frequency and geographic spread of these practices, and their impact on genital health.

\section{P379 PERFORMANCE CHARACTERISTICS OF THE PLEXPCR ${ }^{\circledR}$ VHS ASSAY FOR DETECTION OF TREPONEMA PALLIDUM AND OTHER PATHOGENS IN GENITAL AND EXTRAGENITAL LESIONS}

1J Qquellon*, 1,2S Vargas, ${ }^{1} \mathrm{M}$ Equiluz, ${ }^{1} \mathrm{~F}$ Vasquez, ${ }^{3} \mathrm{G}$ Calvo, ${ }^{3} \mathrm{M}$ Reyes-Diaz, ${ }^{3,4} \mathrm{~K}$ Konda, ${ }^{3} \mathrm{C}$ Caceres, ${ }^{4} \mathrm{~J}$ Klausner. ${ }^{1}$ Sexual Health Laboratory, Center for Interdisciplinary Studies in Sexuality, AIDS and Society, Universidad Peruana Cayetano Heredia, Lima, Peru; ${ }^{2}$ School of Public Health and Administration, Universidad Peruana Cayetano Heredia, Lima, Peru; ${ }^{3}$ Center for Interdisciplinary Studies in Sexuality, AIDS and Society, Universidad Peruana Cayetano Heredia, Lima, Peru; ${ }^{4}$ Division of Infectious Diseases, David Geffen School of Medicine, University of California, Los Angeles, Los Angeles, USA

\subsection{6/sextrans-2021-sti.415}

Background Syndromic management for STIs can result in treating for several pathogens, which can lead to mistreatment and/or overtreatment. We implemented the PlexPCR ${ }^{\circledR}$ VHS, a qualitative real-time PCR assay for simultaneous detection of four pathogens: Treponema pallidum (TP), herpes simplex virus (HSV) types $1 / 2$, and varicella zoster virus (VZV) in genital and extragenital lesions of STI-clinic users diagnosed with early syphilis.

Methods We enrolled patients presenting early syphilis in Lima and Pucallpa, Peru. From any lesions, we collected lesion exudate with a dacron swab in a microtube with $500 \mu$ of lysis buffer, followed by DNA extraction and amplification using a conventional PCR assay to detect tp0574 and tp0548 target genes for TP. DNA samples were also amplified using the PlexPCR $^{\circledR}$ VHS kit (SpeeDx, Australia). We assessed the performance of the PlexPCR ${ }^{\circledR}$ VHS kit TP component and conventional PCR compared to clinical diagnosis.

Results We screened 51 lesions, most (86\%) from patients with primary syphilis, $17 \%$ were atypical syphilis lesions (painful ulcers). PlexPCR ${ }^{\circledR}$ VHS detected only TP among $31 / 51$ (61\%), only HSV-2 among $7 / 51$ (14\%) and four (8\%) coinfections (two of HSV-1/TP and two of HSV-2/TP). Nine $(17 \%)$ were negative for all pathogens (four without detectable DNA) and none were VZV positive. The PlexPCR ${ }^{\circledR}$ VHS kit detected TP in 35/51 (69\%) lesions compared to 29/51 (57\%) detected by conventional PCR, indicating the percent agreement with clinical diagnosis. Among the nine atypical lesions, PlexPCR ${ }^{\circledR}$ VHS found four TP positive and three HSV-2 positive, while conventional PCR detected only three TP positive. Among the cases of primary syphilis, 32/44 (73\%) had detectable TP DNA using PlexPCR ${ }^{\circledR}$ VHS and 27/44 (61\%) using conventional PCR.

Conclusions The PlexPCR ${ }^{\circledR}$ VHS kit increases the accuracy of TP detection from lesion samples. Other STI pathogens were also detected in lesions.

\section{P381 ESTIMATING ADULT GONORRHEA PREVALENCE IN BRAZIL}

1,2P Gaspar*, 3J Rowley, ${ }^{1} \mathrm{~A}$ Pati Pascom, ${ }^{4} \mathrm{~F}$ Martinez, ${ }^{3} \mathrm{E}$ Korenromp, ${ }^{1} \mathrm{G}$ Mendes Pereira, ${ }^{1,5} \mathrm{~A}$ Miranda. ${ }^{1}$ Ministry of Health, Brasilia, Brazil; ${ }^{2}$ University of Brasilia, Brasilia, Brazili ${ }^{3}$ Avenir Health, Geneva, Switzerland; ${ }^{4}$ Global Antibiotic Research and Development Partnership, Geneva, Switzerland; ${ }^{5}$ Federal University of Espirito Santo, Vitória, Brazil

10.1136/sextrans-2021-sti.416

Background Brazil has a nationwide antimicrobial susceptibility surveillance program for Neisseria gonorrhoeae. Gonorrhoea, however, is not a notifiable disease and there are limited data on the burden of infection in the country.

Methods We searched Embase PubMed, LILACS, Scielo for studies in any language providing data on the prevalence of urogenital gonorrhoea in 2000 or later in Brazil, with a sample size of 50 or more, and that used an internationally recognized diagnostic test on urine, urethral, or cervicovaginal specimens. The latest search was done on 10 November, 2020. In addition, we searched abstracts from the Brazilian STI congress (years 2010 to 2019) and Ministry of Health reports. The Spectrum-STI statistical model was used to estimate prevalence trends in 15-49 years-old men and women in the general population (excluding STI patients, HIV-positive populations and Transgender women). Prevalence trends were estimated for sexually active women and men, female sex workers and men who 